\title{
半潜水式海洋構造物の転覆機構に関する一考察（第2 報）
}

\author{
正員宝田直之助* 正員 中嶋 俊 夫* \\ 正員 井上隆 一*
}

A Study on the Capsizing Mechanism of Semi-submersible Platforms (2 nd Report)

by Naonosuke Takarada, Member Toshio Nakajima, Member

Ryuichi Inoue, Member

\begin{abstract}
Summary
In the previous paper, the authors discussed the larger angle of steady tilt can be induced by the wave-induced vertical steady forces on the lower hulls when the semi-submersible platform is moored in regular waves having short period. This curious phenomenon is considered to be dangerous to introduce the capsizing of the platform in violent seaway. However, as many existing rules concerning the platform stability requires the consideration of wind heeling moment for the design of the platform, this wind effects on the steady tilt must be taken into consideration as the another possibility of capsizing phenomenon of the semi-submersible platform.

This second report deals with an investigation of the magnitude of some er:vironmental loadings on a eight-column twin hull semi-submersible platform for finding the possibility of larger steady tilt as well as the platform behaviors in such loading conditions. The timedomain simulation which was introduced in the previous report is used and some of the results are compared with experimental records for the purpose of their validity. Furthermore, the behavior of the semi-submersible platform in the combined environmental factors were studied by the simulation. As a result of study, the following conclusions are made.

1. The magnitude of current and wind induced loadings are comparable as well as that of the resultant steady tilt.

2. The wave-induced drift force and moment can be the same magnitude as other environmental steady forces and moments.

3. The magnitude of the moment due to the wave-induced vertical steady force may be the same order or more comparing with others depending on the submergence of lower hulls.

4. The results obtained by the computer simulation are agreeable with the experimental ones.

5. Concerning with the steady tilt in the combined loading condition, the effects of the wave-induced vertical steady forces on the lower hulls cannot be disregarded in the region where the larger wave-induced drift force arises.
\end{abstract}

\section{1 緒}

言

著者らは前報1)に拈いて, 半潜水式海洋構造物のロワ 一ハルに働く上下方向の波浪定常力による定常転倒モー メントを実験的, 理論的に定量化し, このモーメントが 転覆機構の解明のための重要な要素の一つであることを 報告しだ。またこのような通常小さいと考えられる 2 次の波浪定常力が, 半潜水式海洋構造物の大傾斜を䒩起 するには, 単にこの外力だけでなく, (1)小さな GM, (2)

\footnotetext{
* 住友重機械工業(株)技術本部平塚研究所
}

係留点の高さ，(3)初期傾斜の大きさ等の各要因が複合す ることによることを幾つかの比較例で示した。

しかしながら，一般的に静的復原力の小さい半潜水式 海洋構造物では, 波浪以外の外力（風, 潮流等による外 力）によっても，大きな傾斜が惹起されると考えられ る。従来の船級協会等の安全規則が, 風化よる転倒モ一 メントに対する考慮を踏襲しているのはこのためであ る。

本報は前報と同様に，2口ワーハル， 8 コラム型半潜 水式海洋構造物を検討の対象とし, 波, 風, 潮流のそれ 
ぞれによる外力柇よび転倒モーメントを求めるととも に, これらの単一外力下, さらに複合外力下に拈ける構 造物の定常傾斜等の挙動をシミュレーション手法によっ て求め, 各外力が半潜水式海洋構造物の安定性に及ぼす 影響を明らかにしたものである。

\section{2 供試構造物}

本報において研究対象とした半潜水式海洋構造物は, 前報の 2 ロワーハル， 8 コラム型の水面下構造をもつ供 試模型の 60 倍の構造物である。その主寸法を Table 1 に示す。上部構造については, 日本造船研究協会第 192 研究部会2)（SR 192）が研究対象としているらちの一つ である 2 ロワーハル， 8 コラム型半潜水式海洋構造物の

Table 1 Principal particulars of the semisubmersible platform

\begin{tabular}{|l|r|}
\hline \multicolumn{1}{|c|}{ I TEMS } \\
\hline LENGTH OF LOWER HULLS(L) & $102.0 \mathrm{M}$ \\
\hline BREAOTH OVER LOWER HULLS(B) & $69.6 \mathrm{M}$ \\
\hline DISTANCE BETWEEN LOWER HULLS & $54.0 \mathrm{M}$ \\
\hline DRAFT $(d)$ & $24.0 \mathrm{M}$ \\
\hline DISPLACEMENT( $\triangle)$ & $35,734 . T O \mathrm{~N}$ \\
\hline DIAMETER OF LARGE COLUMN & $12.0 \mathrm{M}$ \\
\hline DIAMETER OF SMALL COLUMN & $6.0 \mathrm{M}$ \\
\hline
\end{tabular}
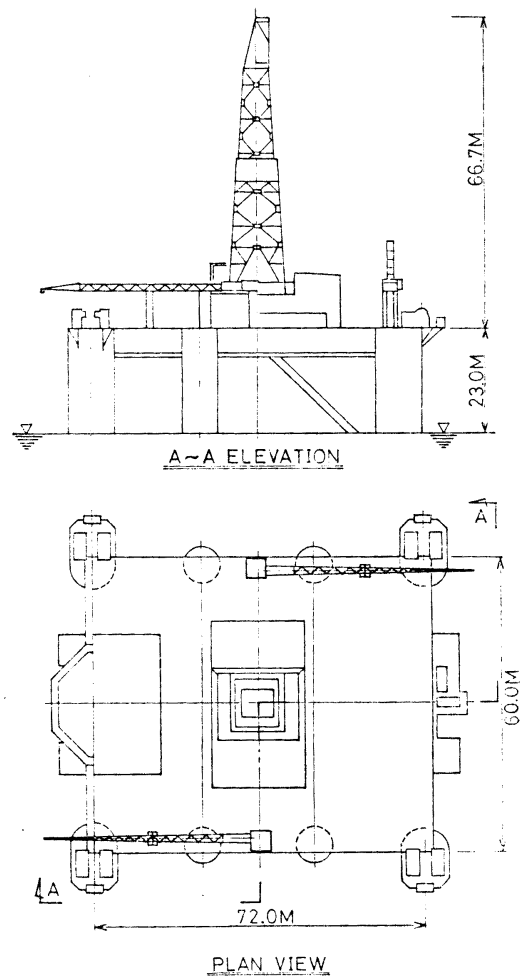

Fig. 1 Outline of the upper structures
上部構造（Fig. 1 参照）と相似構造を想定した。

この供試構造物は，8本の係留鎖により水深 $150 \mathrm{~m}$ の 海域に, 初期張力約 90 ton で係留されているとした。

\section{3 数值シミュレーションの概要}

本報での数值シミュレーションは横波中での 2 次元問 題に限定し，取り扱い上の仮定は前報と同じである。す なわら,

（1）水深を考慮した線形波とする。

（2）各構造部材に比較して波長は十分長いとする。

（3）係留張力は, 各時間ステップに和けるカテナリ 一解を用いる。

座標系を Fig. 2 に示す。波, 風拉よび潮流が $\bar{y}$ の正 方向から構造物に作用する場合を正とする。したがっ て，この場合の波下側へのドリフトは負符号となる。ま た，定常傾斜 $\left(\phi_{0}\right)$ は波下側へ傾斜する場合が正となる。 運動方程式は，前報で示した運動方程式に風圧力およ び潮流力を付加している。

風圧力については，相詨速度を考慮した抗力（ $y$ 方 向), 揚力 ( $z$ 方向) およびモーメント ( を運動方程式の左㲽に加える。ここでは，近似的に各方 向の運動速度と風速のみの相対速度を考慮している。例 完ば, $y$ 方向の風圧力は次式のようになる。

$$
\begin{gathered}
F_{W y}=C_{D} \frac{1}{2} \rho_{A} \cdot A\left|\dot{y}(t)-\bar{z}_{h} \cdot \dot{\phi}(t)+V_{W}\right| \cdot\{\dot{y}(t) \\
\left.-\bar{z}_{h} \cdot \dot{\phi}(t)+V_{W}\right\} \\
こ こ に, F_{W y}: y \text { 方向風圧力 } \\
C_{D}: y \text { 方向風圧力係数 } \\
\rho_{A}: \text { 空気密度 } \\
A: \text { 静止状態での正面投影面積 } \\
\bar{z}_{h}: \text { 重心に対する風圧中心の等価レバーア } \\
\text { 一ム } \\
V_{W}: \text { 風速 }
\end{gathered}
$$

ここでのシミュレーションでは, SR 192 研究部会2) 実験で得られた風圧力係数, 風圧モーメント係数 (Fig. 3 を参照) を利用している。

一方, 潮流力については, 前報の運動方程式の抗力項

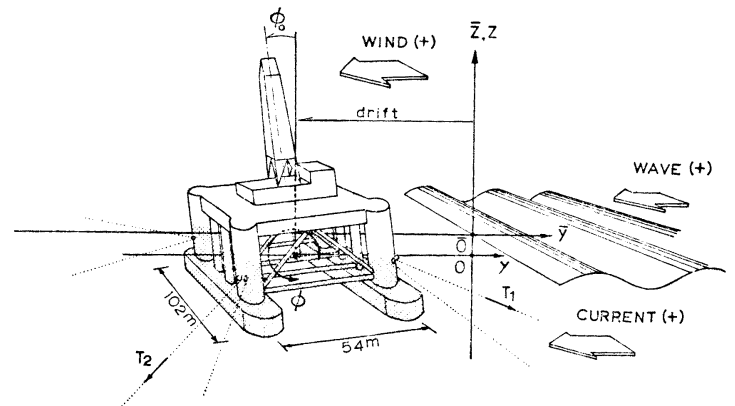

Fig. 2 Coordinate system of simulation 


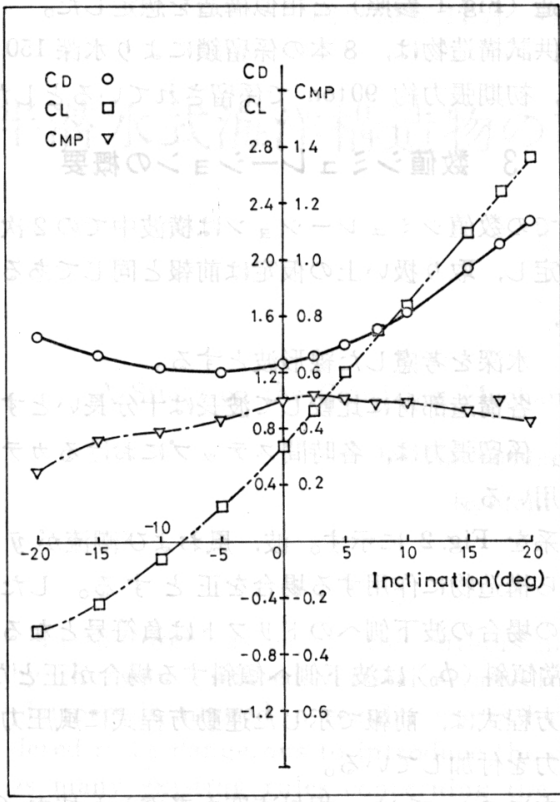

Fig. 3 Drag coefficients of the semi-submersible platform for wind (SR 192 Model)

の相対流速に潮流速度を含める。例えぱ, $y$ 方向につい ては次式のようになる。

$$
\begin{aligned}
& \frac{1}{2} \rho \sum_{m} C_{d y m} \cdot \bar{A}_{y m}\left|\dot{y}(t)-\tilde{z}_{m} \cdot \dot{\phi}(t)-\dot{\xi}_{m}(t)+V_{C}\right| \\
& \times\left\{\dot{y}(t)-\tilde{z}_{m} \cdot \dot{\phi}(t)-\dot{\xi}_{m}(t)+V_{C}\right\} \\
& \text { こに, } \rho: \text { 海水密度 } \\
& C_{d y m}: \text { 構造要素 } m \text { の } y \text { 方向抗力係数 } \\
& \bar{A}_{y m}: \text { 構造要素 } m \text { } y \text { 方向投影面積 } \\
& \tilde{z}_{m}: \text { 重心に対する上下方向レバーアーム } \\
& \dot{\xi}_{m}(t): \text { 波粒子の } y \text { 万向速度 } \\
& V_{C}: \text { 潮流速度 }
\end{aligned}
$$

同様の修正を回転方向についても行う。潮流と波とが同 時に存在する中での没水体の抗力係数に関する問題と似 た性格の研究として, 小寺山ら ${ }^{3)}$ の波浪中を前進する鉛 直没水円柱の流体力に関する実験的研究がある。その中 では，抗力係数を変動成分と定常成分とに分けて考えて お゙り，前進速度が大きい場合に両者はほとんど等しい が，前進速度が小さい場合には差があることが報告され ている。本論で取り扱ら範囲は比較的前進速度の小さい 範囲であるが，ここでは両抗力成分とも定常力の抗力係 数を用いた。具体的には, 半潜水式海洋構造物の水面下 構造を円柱, 角柱等の構成要素に分割し，それぞれの構 成要素に対する抗力係数は，文献 7 ) から推定した。

\section{4 係留実験結果とシミュレーション結果}

前報に示した模型を使用し，潮流中および潮流と波と

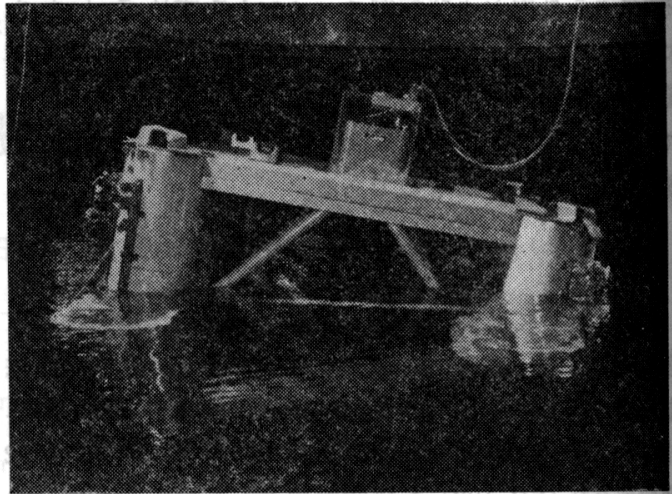

Fig. 4 Photograph showing the steady tilt in current (Tank test)

が同時に存在する中での半潜水式海洋構造物の挙動, あ るいは係留鎖に加わる張力に関する係留実験を実施し た。構造物のドリフトは，上甲板上に設置された光源位 置を平面運動計測用テレビトラッカーで計測した。以下 の実験結果およびこれと比較する場合のシミュレーショ ン結果もこのドリフトを示す。

\section{1 潮流中の実験}

潮流によって上流側に傾斜している模型の写真をFig. 4 に示す。潮流中でのドリフト，定常傾斜および上流䁚 の係留鎖張力の実験記録と時刻歴シミュレーション結果 の比較例をFig. 5 に示す。シミュレーションでは, 実駼 記録の流速を図中に示すように便宜的に直線近似した。 なお，実験での流速計測は模型から上流側に少し離れた 位置で行っており，シミュレーションではこの距離によ る時間遅れの修正を施す必要があるが，ここではそれを 無視している。この時間遅れを考慮して図をみれぱ, 両 者の記録は係留鎖張力の細かいピークを除いてよく一致 していることがわかる。

潮流速度を変化させたとさのドリフト，定常傾斜等を Fig. 6 に示す。Fig. 5 の潮流の実験記録にもみられたよ らに, 流速が速くなると, 実験設備の関係で流速変動が 大きくなり, 定常傾斜等の計測結果にも変動が生し゚る。 したがって，同図ではその変動幅を矢印で示した。実験 結果とシミュレーション結果はよく合っている。シミュ レーション結果において, 係留点の相違により係留鎖㖘 力に差がないにもかかわらず, ドリフトに差があるのは 係留点が高い場合，相対的に緩い係留になっているため である。 


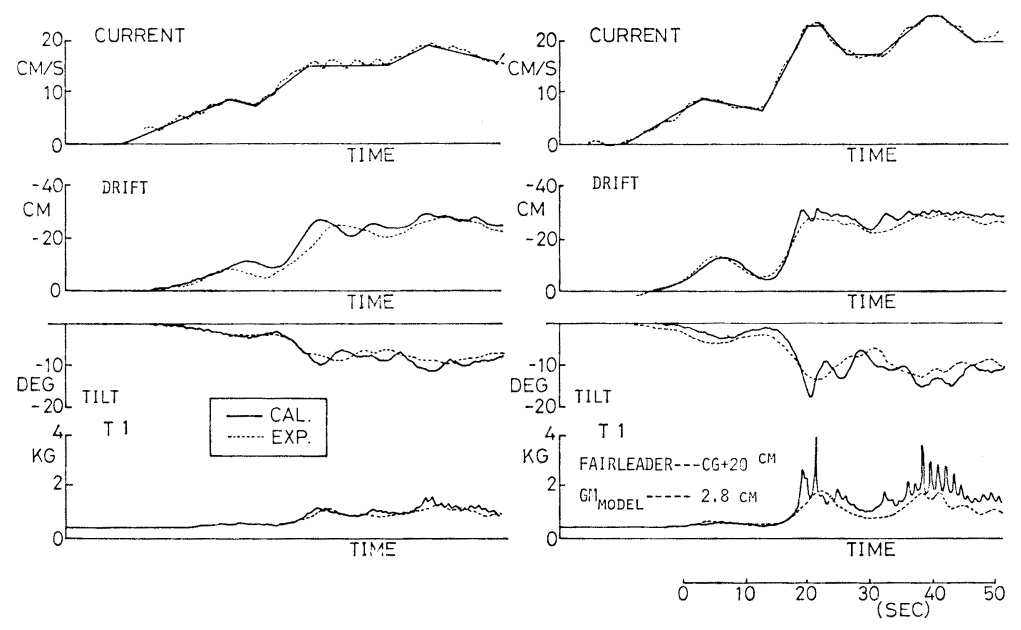

Fig. 5 Comparison of the semi-submersible platform motion in current between experiment and simulation
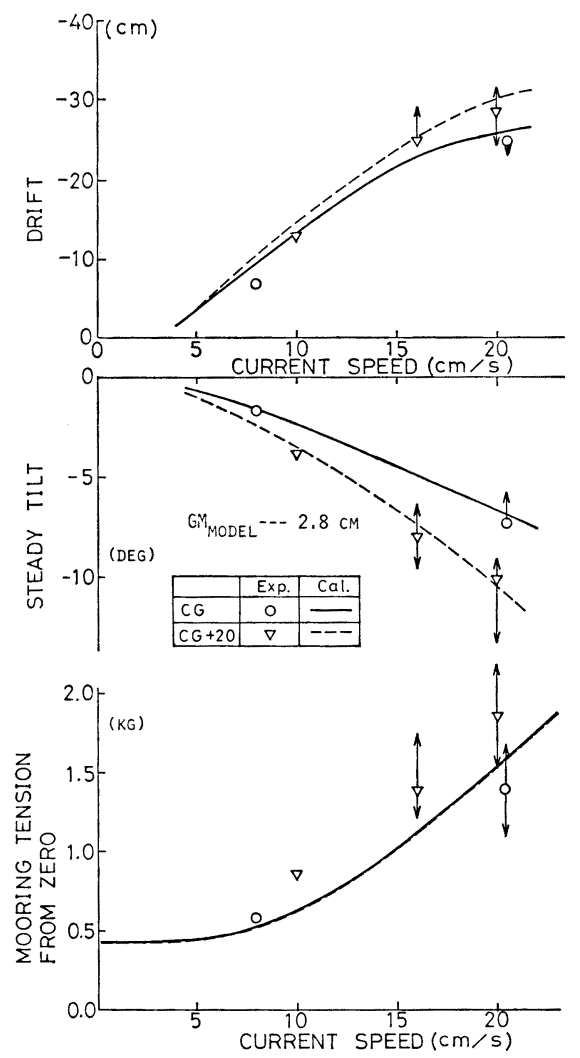

Fig. 6 Drift, steady tilt and mooring tension in current

\section{2 潮流と波とが共存する中での実験}

潮流と波とが同時に存在する場合のシミュレーション は,これらの相互干渉効果を考慮する必要がある。これ らの相互干涉として種々のものが考えられるが，ここで は潮流による波高変化についてのみ考慮する。潮流中に
拈ける波高は，文献 4)，5）により次式で推定する。

$$
H / H_{0}=\left[2 /\left(1+4 V_{C} / C_{0}+\sqrt{1+4 V_{C} / C_{0}}\right]^{1 / 2}\right. \text { (3) }
$$

ここに, $H$ : 潮流と共存する場合の波高

$$
\begin{aligned}
& H_{0}: \text { 波単独時の波高 } \\
& V_{C}: \text { 潮流速度 } \\
& C_{0}: \text { 波速 }
\end{aligned}
$$

（3）式による計算值と実験結果の比較を Fig. 7 に示 す。同図からわかるように，順流中（波と潮流の進行方 向が一致する場合）では波高が低くなり，逆流中では逆 に高くなる。

順流中での模型実験記録と時刻歴シミュレーション結 果の比較例を，Fig. 8 および Fig. 9 に示す。この場合 の係留点は重心より $20 \mathrm{~cm}$ 上方であり, 波高は約 $25 \mathrm{~cm}$ である。半潜水式海洋構造物の挙動については, シミュ レーションにより一応満足できる推定が可能である。し かし，カテナリー理論を用いた係留鎖張力の推定値は， ドリフトが大きい場合にかなり過大な值を与える。ま た，図中の破線は潮流単独時の時刻歴シミュレーション 結果である。半潜水式海洋構造物の挙動が，波との共存 により大きく変化することがわかる。

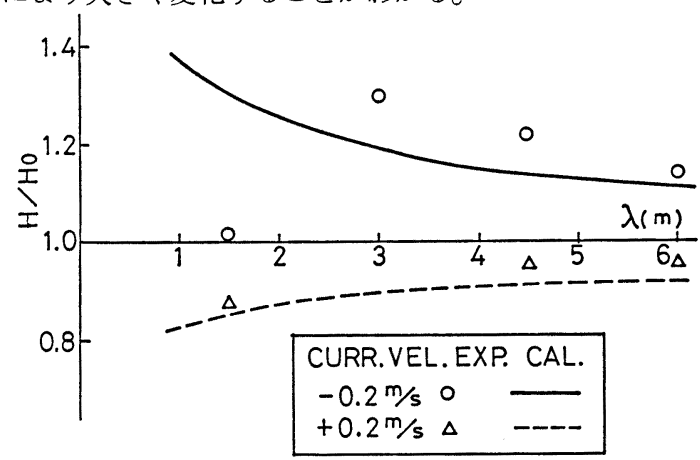

Fig. 7 Effects of current to the wave height 


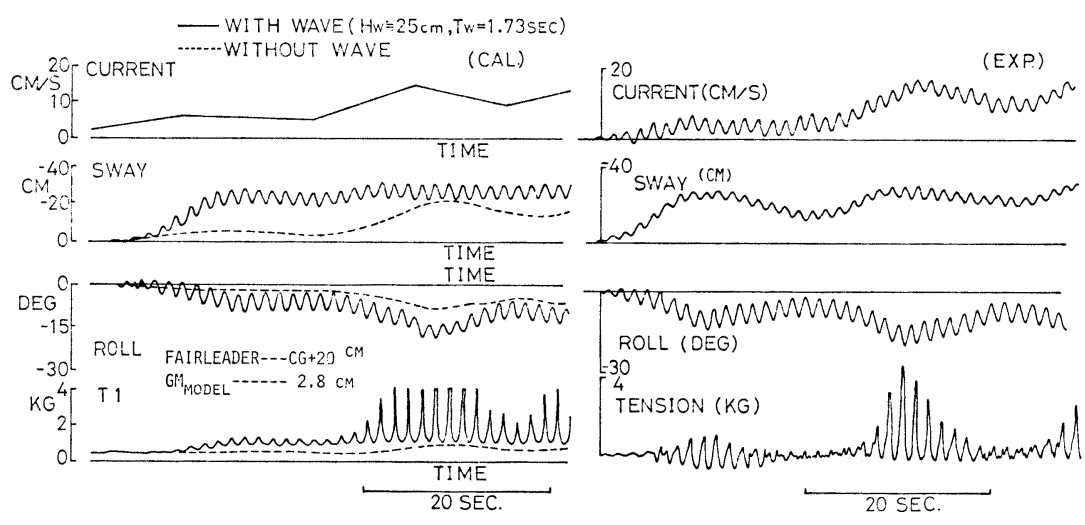

Fig. 8 Comparison of the semi-submersible platform motion in current with/without wave between experiment and simulation

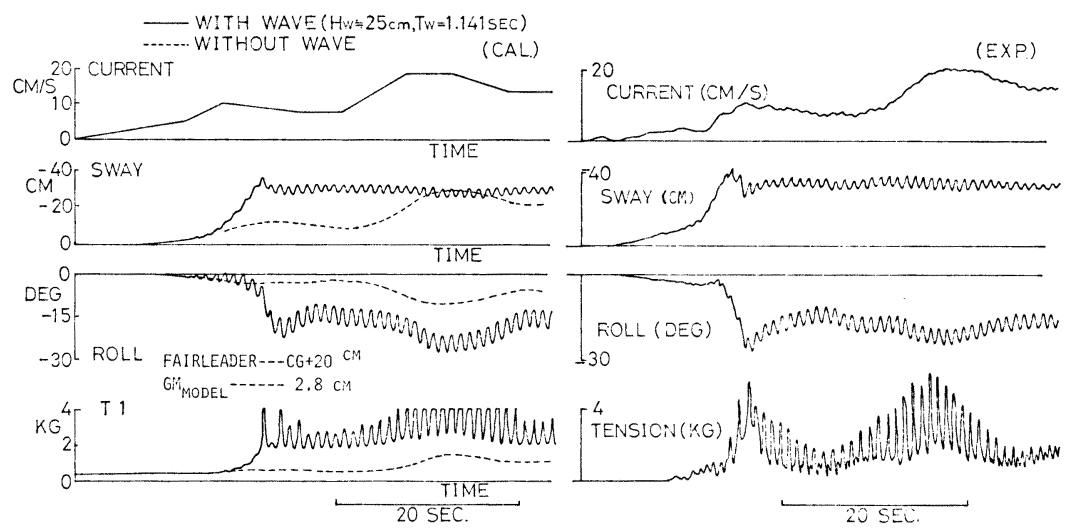

Fig. 9 Comparison of the semi-submersible platform motion in current with/without wave between experiment and simulation

以上のように, シミュレーションにより半潜水式海洋 構造物の挙動をよく推定できることがわかった。以下 に, 種々の状態についてシミュレーションを行った結果 について述べる。

\section{5 風, 潮流および波による定常力／モーメント}

シミュレーションを実施する前に，これに必要な風， 潮流等による定常力／モーメントについて, 概略の比較 を行う。

\section{1 風および潮流による定常力／モーメント}

風あるいは潮流による定常力／モーメントは，それぞ れ（1）式および（2）式において, 運動速度および波 粒子速度を 0 とすれば求められる。

風，潮流による定常力／モーメントを，風速あるいは 潮流速度に対して示したのが Fig. 10 である。ここで想 定した海洋構造物では, 流速約 2.7 ノット時の潮流によ る転倒モーメントが, 風速 70 ノット時の転倒モーメン 卜に相当している。さらに定常力（左右方向）に拈いて は, 約 1.6 ノットの潮流が 70 ノットの風に相当してお
り, 構造物の安定性上, 潮流も風之同程度の影響を与克 得ることがわかる。

\section{2 波による定常力/モーメント}

波による定常力/モーメントについては，前報で詳し く取り扱ったが、ここにその実験結果の一部を再掲す る。Fig. 11 に波漂流力の実験結果, Fig. 12 に定常転倒 モーメントの実験結果および計算結果を示す。

前報において, 波の定常転倒モーメント $\left(M_{H}\right)$ の一つ の取り扱い方として, 直立状態における定常転倒モーメ ント $\left(M_{D}\right)$ と， ロワーハルに働く上下方向定常力によ る定常転倒モーメント $\left(M_{L}\right)$ に分けて考光た。本報で も同様の取り扱いを行い, 前報に示した実験結果を利用 して波高に対する波漂流力および各定常転倒モーメント を求めたものを Fig. 13 に示す。ここで, 波漂流力と直 立状態に括ける定常転倒モーメント $\left(M_{D}\right)$ とが同一の 線で示されているのは, $M_{D}$ は波漂流力とその作用点の 重心からの距離との積であるとし，さらにこの作用点と 重心との距離が波長によって変わらないと仮定したため である。Fig. 13 と前掲の Fig. 10 を見比べると，波傾 

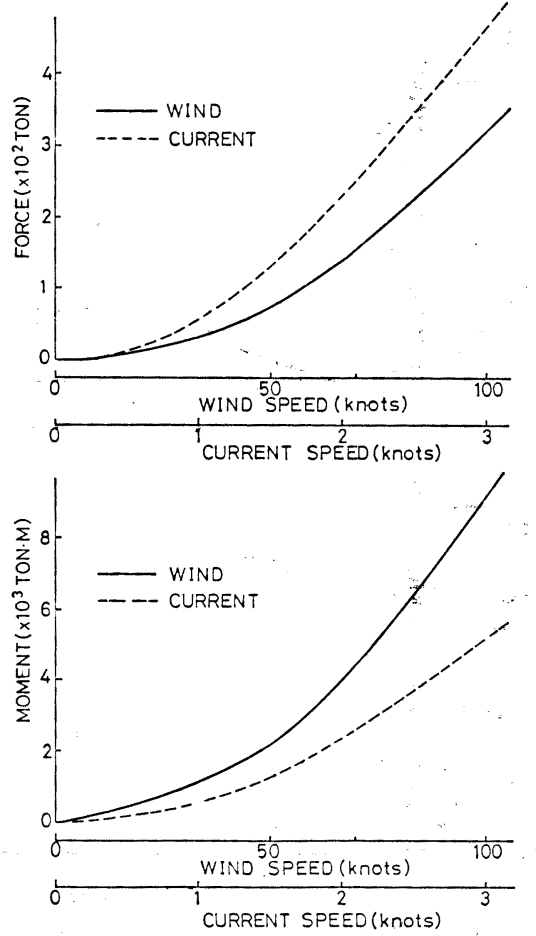

Fig. 10 Horizontal steady forces and steady heeling moments due to current and wind

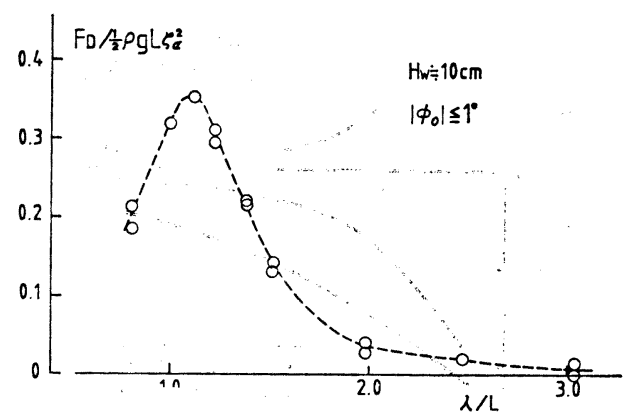

Fig. 11 Drifting force due to waves

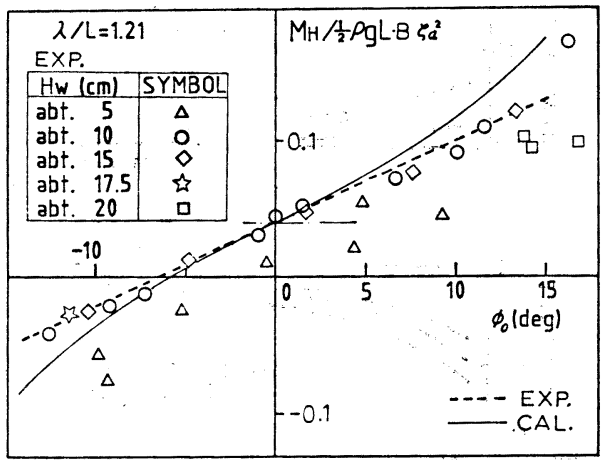

Fig. 12 Steady heeling moment due to waves
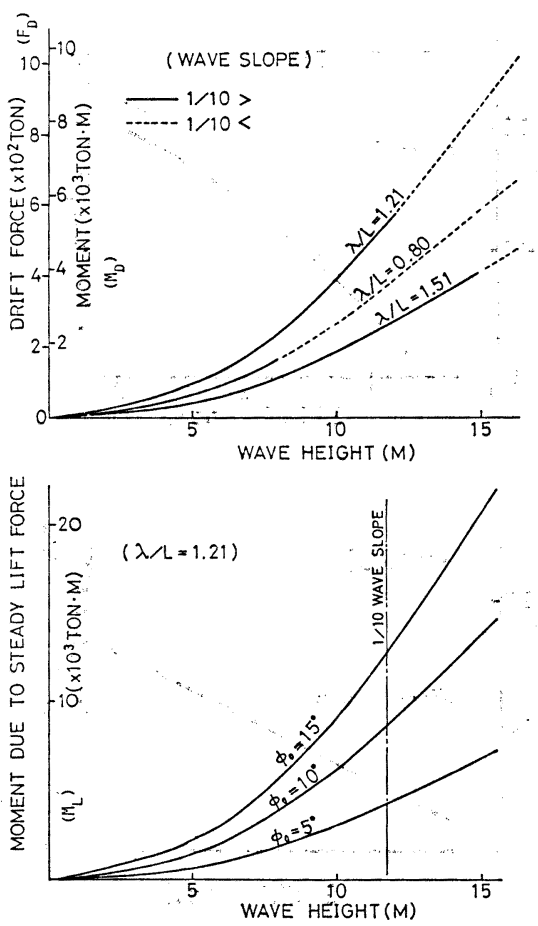

Fig. 13 Drifting forces and steady heeling moments as a function of wave height

斜が $1 / 10$ を超えない範囲でも，“波漂流力および各定常 転倒モーメントは, 風, 潮流による定常力／モーメント と同程度の大きさになることがわかるっ特に，ロワーハ ルに働く上下方向定常力による定常転倒モーメントは, 定常傾斜角が約 $5^{\circ}$ でも，風や潮流による定常転倒モー メントに匹敵する大きなモーメントを著起することがわ かる。

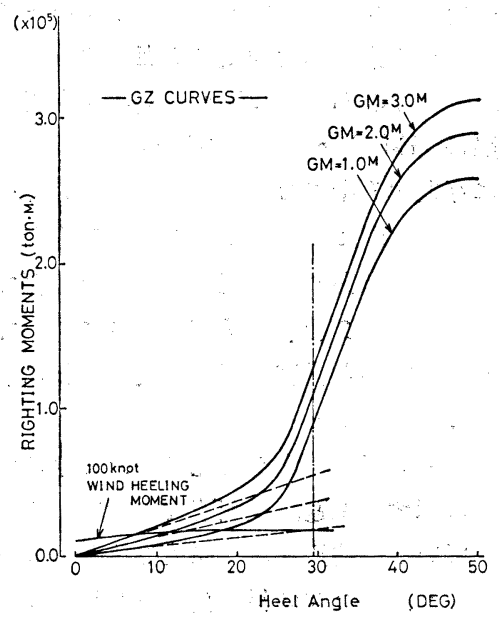

Fig.14 Righting moment curves and wind heeling moment curve 

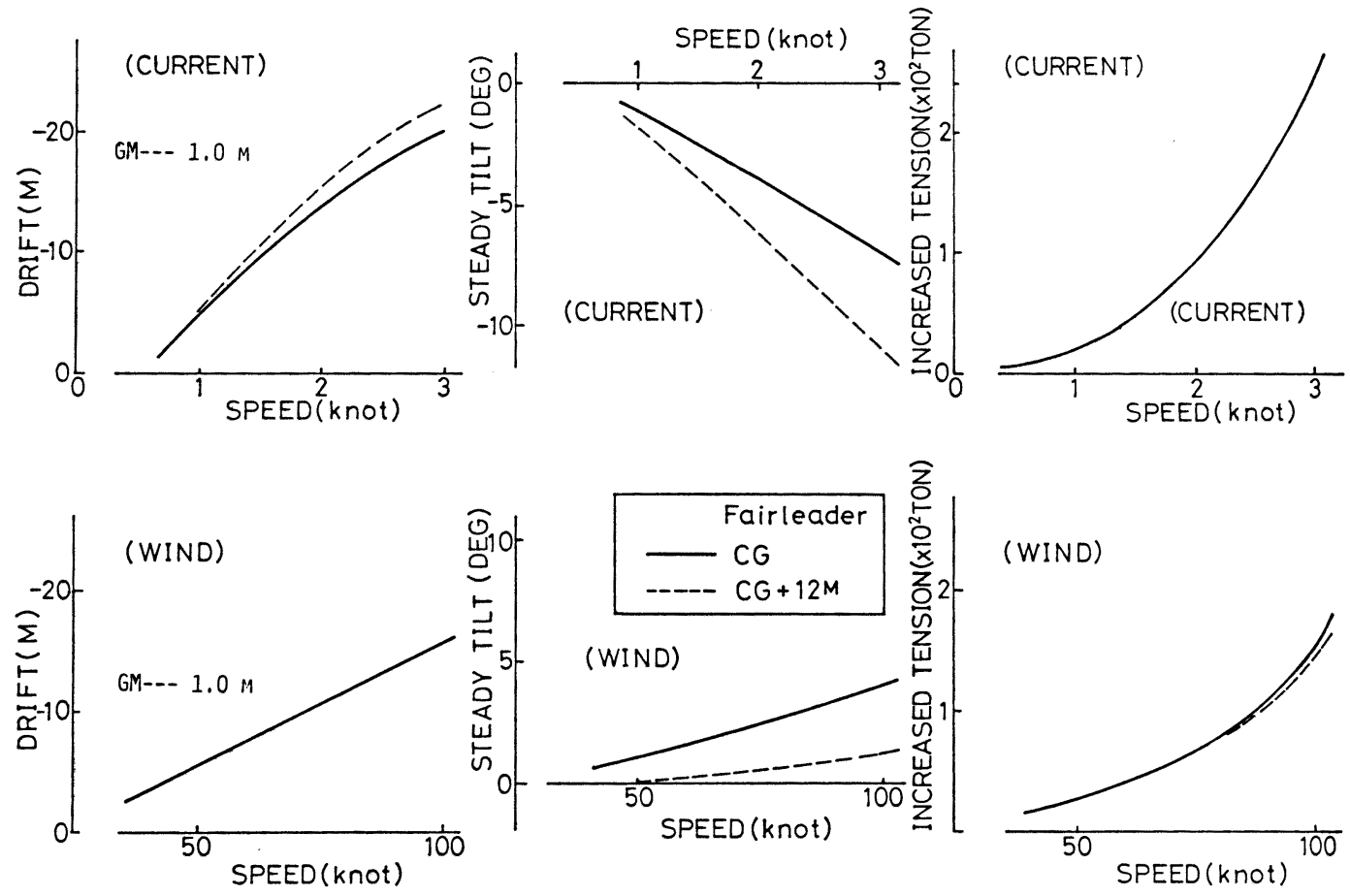

(WIND)

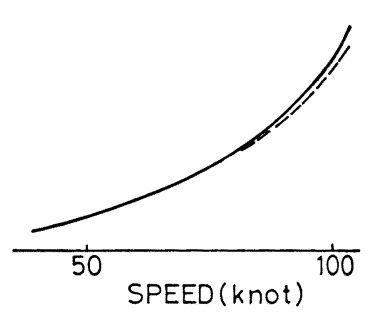

Fig. 15 Simulated results of drifts, steady tilts and mooring tensions in current and wind

\section{6 風, 潮流および波の中での举動}

まず，風，潮流および波がそれぞれ単独に作用する場 合の半潜水式海洋構造物の挙動について, シミュレーシ ョン結果を示す。

Fig. 14 は，ここで検討対象としている半潜水式海洋 構造物のメタセンタ高さを変化させたときの復原モーメ ント曲線を示したものである。同図において, 最も復原 性能が劣るのは $\mathrm{GM}=1.0 \mathrm{~m}$ の状態であるが，この状 態で，航級協会が規定している転倒エネルギーに対する 復原エネルギーの余裕率を満足する海水流入角は, 最低 $29.5^{\circ}$ となる。この $\mathrm{GM}=1.0 \mathrm{~m}$ が船級協会規則を満足 する最下限の $\mathrm{GM}$ と考兄, この状態で風, 潮流がそれ ぞれ単独に存在する中でのシミュレーションを行った。 その結果を Fig. 15 と示す。風が作用する場合の定常傾 斜の方向は風下側であり, 潮流の場合は上流側であるこ とがわかる。また，2状態の係留点高さについて計算を 行っており, 同図から係留点高さの定常傾斜法充る影 響は大きいことがわかる。

各外力下において，GM を变化させたときの定常傾斜 をFig. 16 亿示す。風速, 潮流速度および波の状態は図 中に示されている。波周期は波漂流力係数のピーク付近 飞対応しており，また波傾斜（波高波長比）も1/10で あり, 波の設定条件は風, 潮流の設定条件に比べてやや 厳しいかもしれないが，波による定常傾斜が大きいこと
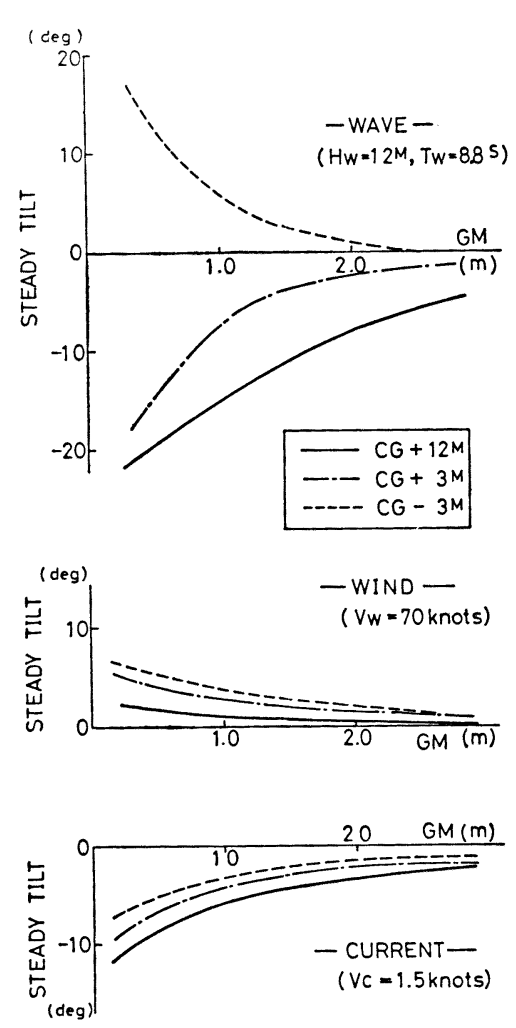

Fig. 16 Simulated results of steady tilts in waves, current and wind 


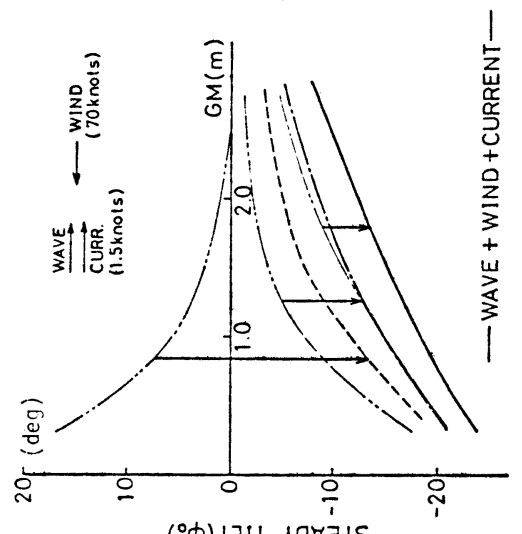

(०๑) $1711 \quad 10 \forall \exists 15$
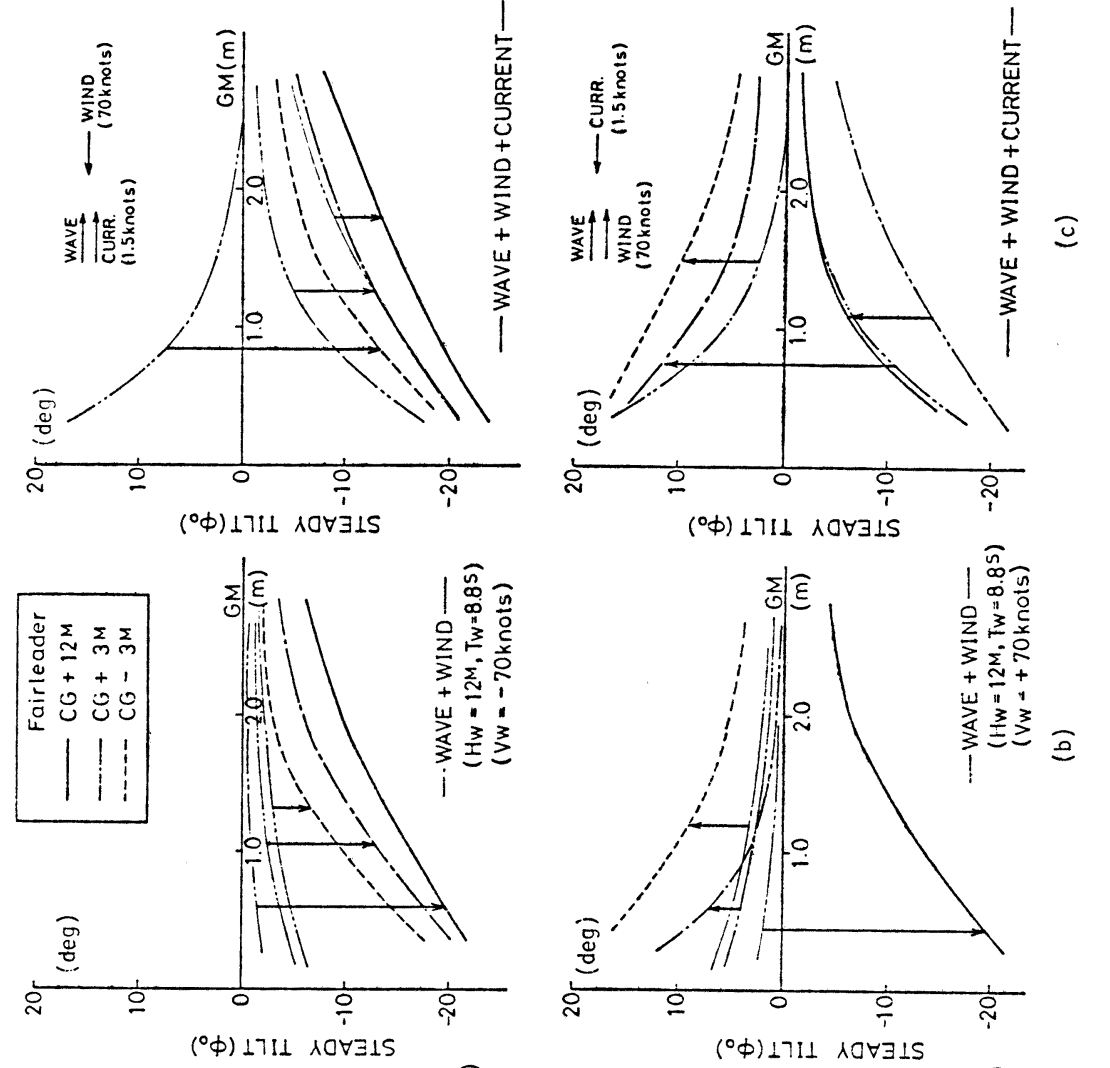

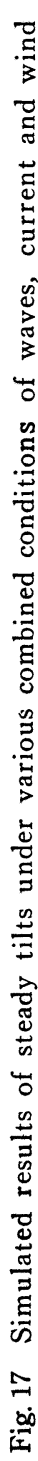
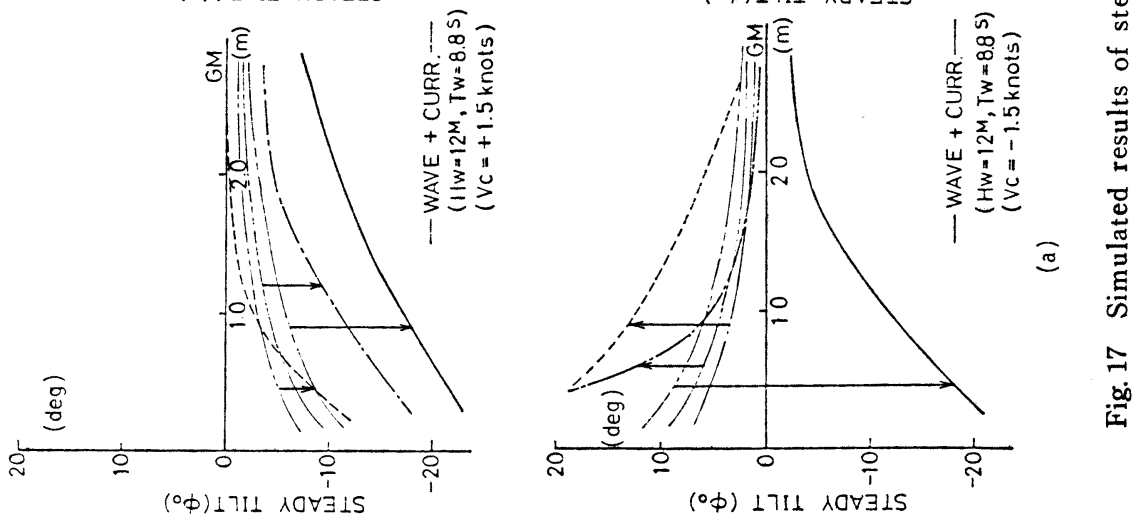
がわかる。また，係留点高さの影響が大きく，その設定 によっては船級協会規則を満足する $\mathrm{GM}=1.0 \mathrm{~m}$ の状 態でも，大傾斜を防止するには充分とは言い難い。

\section{7 風, 潮流および波が共存する中での定常傾斜}

次に，風，潮流および波が同時に存在する中での定常 傾斜についてのシミュレーション結果を Fig. 17 に示す。

Fig. 17(a) に, 流速 1.5 ノットの潮流が波に対して 順流または逆流状態で，波と共存する場合の結果を示 す。四中の 2 点鎖線は潮流のみが存在する場合の結果を 示しており，波の到来によって矢印の方向に定常傾斜が 変化する。また, 風之波について同様の解析を行った結 果を Fig. 17(b) に示す。図中の 2 点鎖線は風のみが存 在する場合の結果を示す。これら Fig. 17(a)，(b) は ともに, 波漂流力／定常転倒モーメントの大きい波周期 の波との共存により，定常傾斜が風，または潮流単独の 場合より遙かに大きくなることを示している。

Fig. 17（c）に，風，潮流および波が共存する場合の 定常傾斜の一例を示す。図中の 2 点鎖線は，波のみが存 在する場合の定常傾斜を示しているが，他の外力の作用 で大きく変化しているようすがわかる。

Fig. 17 では, 複合外力下における半潜水式海洋構造 物の定常傾斜角に対する GM の影響の傾向をみた。し かし、これらの結果だけから GM の許容限界を論ずる ことは早計であるが， $\mathrm{GM}=1.0 \mathrm{~m}$ は大傾斜の防止の観 点からは，かなり下限に近いように思われる。

\section{8 結 ……言}

本報では, 係留された半潜水式海洋構造物が通常遭遇 する風，潮流，波による外力およびそれらによる定常傾 斜等の挙動についての検討を行った。その結果，次のこ とが明らかになった。

（1）風，潮流による外力および転倒モーメントの大 きさは，ほぼ同程度である。

（2）潮流によっても，風によるものと同程度あるい はそれ以上の定常傾斜が起こり得る。

（3）波漂流力および直立状態における定常転倒モー メントは，風，潮流による定常力および転倒モーメント とほぼ同程度の大きさになり得る。

（4）ロワーハルに働く上下方向波浪定常力による転 倒モーメントも，他の外力による転倒モーメントと比較 すると，同程度かあるいはそれ以上になることがある。 したがって, 直立状態の定常転倒モーメントを含めて, 波による定常傾斜を無視し得ない。

（5）また, 風, 潮流, 波が同時に存在するときの挙
動については，以下の知見を得た。

i ）潮流と波が共存するときの挙動シミュレーショ ンによる解析は，実験結果とほぼ一致する。ただ し, 係留張力については, さらに改良する必要があ る。

ii）風と波, あるいは潮流と波が共存する場合です 波漂流力の大きい波周期範囲では，波による転倒モ ーメントが支配的である。

iii） GM 值の限界は， GZ 曲線に関連する取り扱い のみならず，大傾斜を防止する視点からも求められ るべきであろら。

iv）係留された半潜水式海洋構造物の安全性基準は, 単に風だけでなく、波や潮流を含めた総合的な検討 が重要である。これらの総合検討結果は次報にとり まとめて報告する予定である。

謝辞

最後に, 本研究に対し, 御助言・御討論頂いた防衛大 学校 別所正利教授, 横浜国立大学 竹沢誠二教授, 実 験結果等を使用させて頂いた日本造船研究協会第 192 研 究部会の各位に深く御礼申し上げます。

\section{参考 文 献}

1) 宝田直之助, 中鴆俊夫, 井上隆一：半潜水式海洋 構造物の転覆機構に関する一考察 (第 1 報), 日 本造船学会論文集，第 155 号 (昭和 59 年 6 月).

2）日本造船研究協会：海洋構造物の設計外力および 復原性に関する研究, 第 192 研究部会報告書 (昭 和 59 年 3 月).

3）小寺山亘, 田代昭正：波浪中を前進する鉛直円柱 に加わる流体力についての実験的研究 (第 2 報), 西部造船会会報，第 64 号 (昭和 57 年 5 月).

4）磯崎一郎：関東沖の北東の風波におよぼす黒潮の 効果について, 気象庁・研究時報, 第 10 巻, 第 3 号 (1958).

5）大川 豊：海洋波の变形，日本造船学会誌，第 609 号 (昭和 55 年 3 月).

6）安藤定雄, 星野邦弘, 三島木絹子：一樣流中にお ける波浪の変形について, 運輸省船舶技術研究所 研究発表会講演集, 第 38 回 (昭和 56 年 12 月).

7) Hoerner, S. F.: Fluid Dynamic Drag (1965).

8) Takarada, N., Obokata, J., Inoue, R., Nakaji. ma, T. and Kobayashi, K.: The Stability on Semi-submersible Platform in Waves (On the Capsizing of Moored Semi-submersible Plat. form), The 2 nd International Conference on Stability of Ships and Ocean Vehicles (Oct. 1982).

9) Numata, E., Michel, W.H. and McClure, A. C.: Assessement of Stability Requirements for Semi-submersible Unit, T. SNAME (Nov. 1976). 